\title{
Bats of Alpi Marittime Nature Park (North West Italy) and Site of Community Importance IT1160056: distribution and status
}

\author{
Roberto Toffoli $^{1 *}$, Paola Culasso ${ }^{1}$, Andrea G. Locatelli ${ }^{1,2}$, Luca Giraudo ${ }^{3}$
}

\begin{abstract}
A survey of bats was carried out at Alpi Marittime Nature Park and more generally within Site of Community Importance (SIC) IT1160056 from April 1991 to January 2015, using different techniques such as: mist-netting, acoustic sampling and roost surveys. Twenty-one species of bats were detected (Rhinolophus ferrumequinum, Rhinolophus hipposideros, Myotis bechsteinii, Myotis daubentonii, Myotis emarginatus, Myotis myotis, Myotis mystacinus, Myotis nattereri, Myotis oxygnathus, Pipistrellus kuhlii, Pipistrellus nathusii, Pipistrellus pipistrellus, Pipistrellus pygmaeus, Nyctalus leisleri, Hypsugo savii, Eptesicus nilssonii, Eptesicus serotinus, Barbastella barbastellus, Plecotus auritus, Plecotus macrobullaris, Tadarida teniotis). Species diversity is higher in this area than in other Alpine protected areas of a similar size.

Records of E. nilssonii, P. pygmaeus and P. macrobullaris in the study area contribute to the knowledge of the distribution of these species in Piedmont and more generally in Italy. In particular, thanks to records of E. nilssonii, its geographic range could be extended to the western part of the Alps whereas it previously seemed to be only present in the Central-Eastern Alps.
\end{abstract}

Key words: Chiroptera, Bats, Maritime Alps, distribution, status.

Riassunto - I chirotteri del Parco Naturale Alpi Marittime e del Sito d'Importanza Comunitaria IT1160056: distribuzione e status.

Sono stati censiti i Chirotteri nel Parco Naturale Alpi Marittime e più in generale nel Sito di Importanza Comunitaria IT1160056 dall'aprile 1991 a gennaio 2015 mediante catture con mist-nets, ricerca rifugi e indagini bioacustiche. Sono state rilevate 21 specie di Chirotteri (Rhinolophus ferrumequinum, Rhinolophus hipposideros, Myotis bechsteinii, Myotis daubentonii, Myotis emarginatus, Myotis myotis, Myotis mystacinus, Myotis nattereri, Myotis oxygnathus, Pipistrellus

${ }^{1}$ Chirosphera, Associazione per lo Studio e la Tutela dei Chirotteri e l'Ambiente, Via Tetti Barbiere 11, 10026 Santena (TO), Italia. E-mail: chirosphera@gmail.com

${ }^{2}$ School of Biology and Environmental Sciences, University College of Dublin, Belfield, Dublin 4, Dublin, Ireland.

E-mail: andreag.locatelli@gmail.com

${ }^{3}$ Parco Naturale Alpi Marittime, Piazza Regina Elena 30, 12010 Valdieri $(\mathrm{CN})$, Italia.

E-mail: luca.giraudo@parcoalpimarittime.it

* Corresponding author: rtoffoli@iol.it

(C) 2016 Roberto Toffoli, Paola Culasso, Andrea G. Locatelli, Luca Giraudo

Received: 23 February 2016

Accepted for publication: 7 April 2016 kuhlii, Pipistrellus nathusii, Pipistrellus pipistrellus, Pipistrellus pygmaeus, Nyctalus leisleri, Hypsugo savii, Eptesicus nilssonii, Eptesicus serotinus, Barbastella barbastellus, Plecotus auritus, Plecotus macrobullaris, Tadarida teniotis). La ricchezza di specie appare elevata se paragonata a quella di altre aree protette alpine di superficie analoga.

Le segnalazioni di E. nilssonii, P. pygmaeus e $P$. macrobullaris nell'area di studio contribuiscono alla conoscenza della distribuzione di queste specie in Piemonte e più in generale in Italia. In particolare per E. nilssonii viene ampliata la sua distribuzione sul territorio nazionale limitata finora al solo settore centro orientale dell'arco alpino italiano.

Parole chiave: Chiroptera, Pipistrelli, Alpi Marittime, Distribuzione, Status.

\section{INTRODUCTION}

The Maritime Alps are a priority area for wildlife conservation as they are rich in endemic, rare and endangered species (La Posta \& Dupré, 2008). The current knowledge of faunal biodiversity and species distribution in this region has been considerably improved thanks to a recent generalized biological inventory project, which collected data for about 10,000 taxa between 2007 and 2012 (Leccia, 2012).

Until the early 1990s little historical information on bats was available, this was based on work by Sindaco et al. (1992). Later, a more complete checklist was published by Toffoli (1999).

More recently, the region was studied in greater detail with different methods. These included the implementation of specific long-term monitoring in winter and reproductive roosts (Culasso \& Toffoli, 2010; Debernardi et al., 2010 ) and the investigation of habitat selection for some selected species (Locatelli \& Toffoli, 2014). The aim of previous studies was primarily to develop effective strategies for species conservation.

The present paper illustrates the overview of the current distribution and conservation status of bats in the study area and more generally within the Site of Community Importance (SCI) IT1160056 Alpi Marittime, based on the surveys conducted in the last two decades.

\section{Study area}

The survey was carried out in the area of the SCI IT1160056 Alpi Marittime, which includes Aisone, Entracque, Limone Piemonte, Roaschia, Valdieri and Ver- 
nante municipalities in the province of Cuneo (North West Italy; $\left.44^{\circ} 12^{\prime} \mathrm{N}, 7^{\circ} 20^{\prime} \mathrm{E}\right)$, and within a $5 \mathrm{~km}$ buffer all around the site (Fig. 1). Alpi Marittime Nature Park is located within SCI boundaries. It is worth mentioning that the western boundary of the Alpi Marittime Nature Park coincides with much of the eastern boundary of Mercantour National Park.

The selected region extends across an area of 33,673 ha. It is characterized by a large diversity of habitats and wide altitudinal gradient (from a minimum of $750 \mathrm{~m}$ a.s.l. in the valley bottom to a maximum of $3297 \mathrm{~m}$ a.s.1. of the peak of Argentera), a varied lithology (limestone and crystalline rocks) and climate diversity (from strictly alpine to more temperate). The abundance of different microclimates was a factor that led to the current presence of many endemic species both of flora and fauna with an extremely restricted distribution range (Leccia, 2012).

The Alpi Marittime Nature Park and SCI area is mainly alpine and is characterized by a large rock cover (about $47 \%$ of total extent). Both coniferous and deciduous woodlands are present. The former are primarily characterized by beech forests, which are almost always homogeneous. The latter are abundant due to the conformation of the mountains that limit humid currents ascending the lower part of the valleys and accentuating the continental weather.

In the SCI there are few cave complexes. Among them, the most important is the Grotte del Bandito, which opens near the Gesso river, near Roaschia, $750 \mathrm{~m}$ a.s.l. This un- derground complex is currently protected from human disturbance by gates, which allow bats to pass through. Lots of bunkers excavated for military purposes during World War II and some mines are also present.

\section{MATERIALS AND METHODS}

Surveys were conducted with different techniques at altitudes between $700 \mathrm{~m}$ and $2100 \mathrm{~m}$ a.s.l. from April 1991 to January 2015. A total of 935 hours were dedicated to activity on the field. Data were collected during all months of the year with two peaks between June and September and December-January each year.

\section{Mist-netting}

Bats were captured with nylon mist-nets with a mesh size of 16 to $19 \mathrm{~mm}$ (Agnelli et al., 2004). Captures were distributed homogeneously throughout the study area, in all the different environmental types. Mist-nets were positioned along flight paths, foraging areas, water bodies and near underground sites. All nets were checked every 10 minutes and captured bats were immediately placed in cloth bags awaiting species identification and measuring. Before release bats were marked with atoxic paint, if recaptured they were immediately released to minimize stress to the animals and avoid double counting. Species identification was carried out according to Roesli \& Moretti (2000), Dietz \& von Helversen (2004), Marchesi et al. (2008), Dietz et al. (2009), Arthur \& Lemaire (2009), Dietz \& Kiefer (2014).
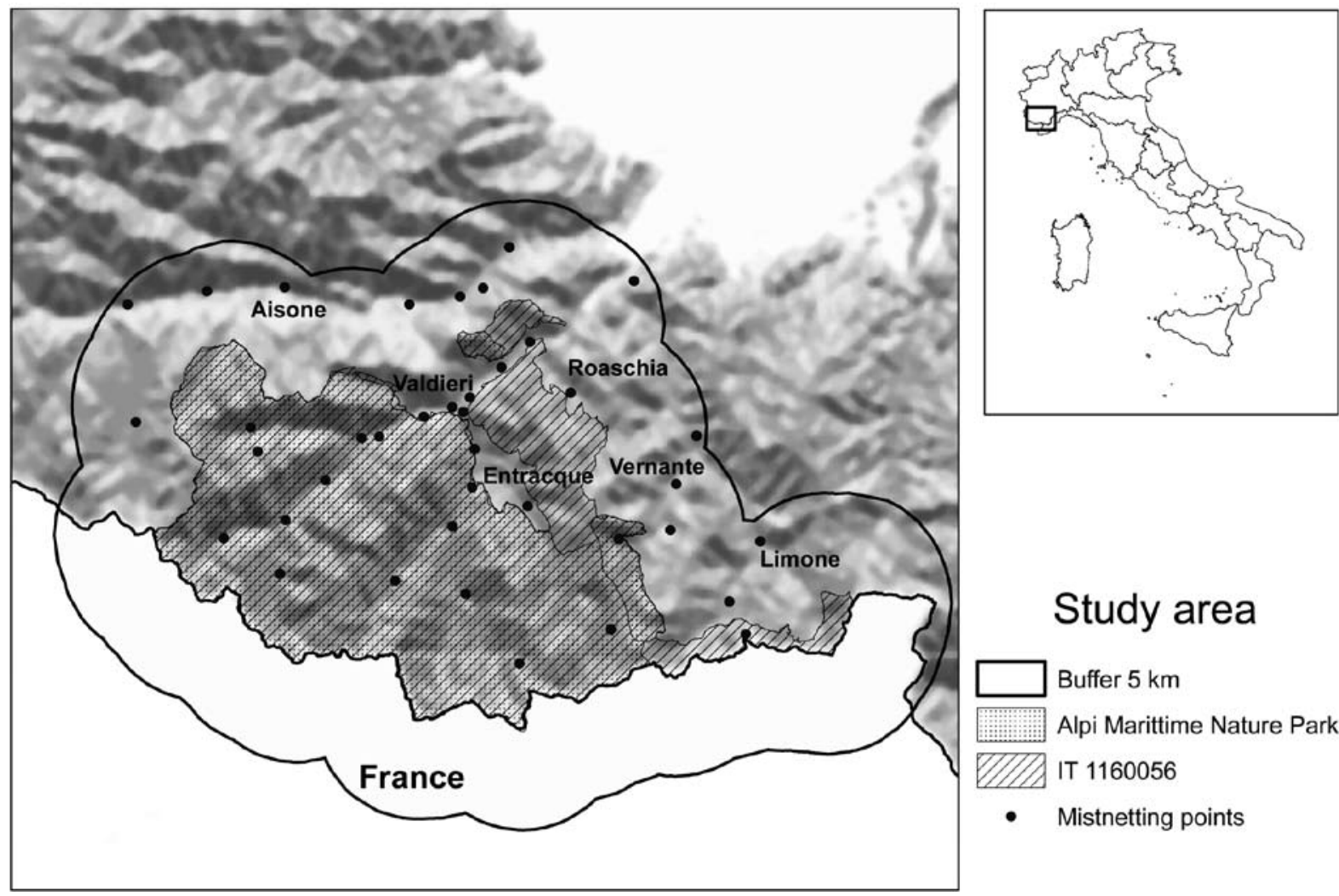

Fig. 1 - Study area and mist-netting points. / Area di studio e localizzazione dei punti di cattura.

\section{Study area}

Buffer $5 \mathrm{~km}$

Alpi Marittime Nature Park

IT 1160056

- Mistnetting points 
As for individuals belonging to the genus Plecotus, the groups Myotis mystacinus/alcathoe/brandtii and Pipistrellus pipistrellus/pygmaeus, species discrimination followed criteria proposed by Dietz \& Von Helversen (2004) integrated with Dietz et al. (2009) and Arthur \& Lemaire (2009). For uncertain cases, biopsy samples of patagium were taken for molecular identification at the Department of Biotechnology and Biosciences of the University of Milano Bicocca by DNA barcoding standardized protocol.

It was possible to classify individuals as juveniles or adults by examining the degree of calcification of phalanx epiphyses (Dietz \& Von Helversen, 2004; Brunet-Rossini $\&$ Wilkinson, 2009). Females were further classified as lactating and not lactating, based on the condition of nipples. Males were classified based on the development of their buccal glands and the degree of swelling of epididymis and testes (Haarsma, 2008).

All animals captured were always released within a few minutes to avoid stress.

Catches were made with permission of the Italian Ministry of the Environment (Refs. SNC/2D/2001/14644; $\mathrm{DCN} / 2 \mathrm{D} / 2003 / 13867$; DPN/2008/0001053; DPN/2010/0011879; 000882/PNM/08052014).

\section{Roosts survey}

Surveys aimed to locate and inspect summer, winter or temporary roosts and involved abandoned buildings, churches, bridges and underground natural and artificial sites, which were considered suitable for roosting bats. Sites were inspected during daylight to detect the presence of bats, or traces of their presence such as droppings, food remains or dead individuals.

When guano accumulation was found, samples were collected to search for hairs (resulting from fur cleaning activity) for the identification of species or genus (Pierallini et al., 2004).

As for swarming sites, the research was carried out by catching bats with mist-nets in the proximity of potential roosting sites, such as cavities during late summer and autumn. Intense flight activity in and around the site, large and transient, multi species bat assemblage, large number of individuals with a predominance in males, during August and September were considered to be consistent with swarming activity.

Some breeding and wintering sites have been regularly monitored since 1995, by counting individuals inside. Wintering sites have been sampled just a single time per winter in the period between mid-December and the end of February in order to minimize disturbance. Observations in the breeding sites have been realized between June and July with infrared cameras enabling counting of individuals within the colonies.

\section{Bioacoustics analysis}

Ultrasound detection of bats has been carried out since 2003 by using time expansion D240X and D 980 bat detectors (Pettersson Elektronik AB, Uppsala, Sweden) recording signals on Edirol D09 device (Roland Corporation, Hamamatsu, Japan), and D1000 bat detector (Pettersson Elektronik AB, Uppsala, Sweden), Elekon Baltlogger (Elekon AG, Luzern Switzerland) and Wildlife Acoustics SM2BAT+
(Wildlife Acoustics, Inc., Maynard, MA, USA) in real time. Echolocation signals were then measured and analyzed with BatSound Pro 4.03 (Pettersson, 2008) at a sampling rate of 44100 (16 bit) through a Hamming window of 512 samples.

Species identification was obtained by analyzing each bat call sequence following the methodological approach provided by Barataud (2012) and comparing the data with those published by Russo \& Jones (2002). The identification method is based on the signal shape, the energy peak distribution and on the measurement of the following parameters: start frequency $(\mathrm{SF})$, end frequency $(\mathrm{EF})$, bandwidth (BW), frequency of maximum energy (FME) in $\mathrm{kHz}$, duration (D) and inter-pulse interval in ms (IPI).

Echolocation sequences with alternating call structure and frequency ( 33 and $42 \mathrm{kHz}$ ) were classified as Barbastella barbastellus (Denzinger et al., 2001; Barataud, 2012).

The FME was used to identify signals with a frequency modulation followed by a quasi-constant frequency (FM/ QCF) of species belonging to the Pipistrellus genus (Pipistrellus pipistrellus, Pipistrellus pygmaeus and Pipistrellus kuhlii/nathusii).

Pipistrellus nathusii was associated only to calls characterized by a quasi-constant frequency (QCF) structure with FME between 39 and $42 \mathrm{kHz}$ (Barataud, 2012).

Pipistrellus kuhlii was identified only by call with QCF structure and FME equal to $36-39 \mathrm{kHz}$.

All FM/QCF signals with a FME between 37 and 43 $\mathrm{kHz}$ were classified of Pipistrellus kuhlii/nathusii. At these frequency values, these two species were correctly identified only in sequences containing social calls, considered to be distinctive at specific level (Russo \& Jones, 1999; Pfalzer \& Kusch, 2003).

The identification of Pipistrellus pygmaeus relied on QCF signals with a FME equal to $54-56 \mathrm{kHz}$ or FM/QCF signals with a FME higher than $56 \mathrm{kHz}$.

Hypsugo savii identification was made by referring to QCF calls with a FME equal to $30-34 \mathrm{kHz}$.

For sequences with FME signals from 20 to $30 \mathrm{kHz}$ the presence of characteristic alternate $\mathrm{FM} / \mathrm{QCF}$ and QCF signals of different FME was associated to the Nyctalus genus (Waters et al, 1995; Barataud, 2012).

QCF signals with a peak frequency equal to $27-29 \mathrm{kHz}$ were used to recognise Eptesicus nilssonii.

Eptesicus serotinus was identified by sequences of primarily FM/QCF signals either longer than 17 milliseconds (ms) and with end frequency between 21 and $24 \mathrm{kHz}$ or shorter than $5 \mathrm{~ms}$ and with EF between 29 and $32 \mathrm{kHz}$ (Barataud, 2012). This was to avoid parameter overlap with other species, which use similar calls.

All sequences with steep FM signals were attributed to Myotis genus and different species were identified rigorously following the method described by Barataud (2005; 2012), by measuring SF, EF, BW, FME, D, IPI and by shape of the signals. All signals presenting a structure that could not be attributed to a single species were listed as Myotis sp.

Due to a lack of firm discrimination criteria for bioacoustic distinction between Plecotus auritus, Plecotus austriacus and Plecotus macrobullaris, we listed all signals of the genus as Plecotus sp. 
In general, when social calls were present, they were considered to be distinctive at specific level (Pfalzer, 2002; Pfalzer \& Kusch, 2003; Middleton et al., 2014).

\section{Data analysis}

Taxa identified to species level and detected with all different methodologies were mapped on a $1 \mathrm{~km}$ grid cell size overlaid onto the study area. Taxonomy and nomenclature according to Lanza (2012) and Dietz \& Kiefer (2014).

Regarding Myotis nattereri (sensu lato), although it has been recently split into a complex of cryptic species on the basis of genetic evidence (Salicini et al., 2011; Puechemaille et al., 2012), here we still prefer to use the nomenclature Myotis nattereri as suggested by Lanza (2012), without any further distinction.

\section{RESULTS}

We collected data for 628 presences of 21 bat species within 60 sampling areas (Tab. 1). Thirteen of these species were detected by bioacoustic surveys.

Eighteen species were captured using mist-nets, with a total of 269 individuals (Tab. 2). The most frequently captured species was Myotis emarginatus, followed by Myotis daubentonii, Hypsugo savii, Pipistrellus pipistrellus and Barbastella barbastellus.

We identified 29 roosts, where we found 15 species. Nine of these are reproductive roosts $(29 \%), 10$ wintering $(32 \%)$ and 12 are sites of temporary aggregation $(39 \%)$.

Only one species, Pipistrellus nathusii, was never captured nor was found in any roost, but was recorded exclusively by bioacoustic surveys, for the first time in the study area.

The most common species, recorded with the three survey methods, was Pipistrellus pipistrellus which was reported in $75.0 \%$ of the sampling areas. Hypsugo savii and Nyctalus leisleri were detected in $36.7 \%$ and $31.7 \%$ of the cells, respectively (Fig. 2). Myotis bechsteinii, Pipistrellus pygmaeus and Plecotus macrobullaris were the least frequently encountered species. Their presence was only confirmed inside a single kilometric square. The status and distribution of each species is showed in the checklist below. Note that, for conservation purposes, the exact location of roosts is not reported (except for municipality), with the exception of sites currently subjected to special protection.

Tab. 1 - List of detected species and the number of acoustic samples or individuals identified with each different survey technique.

\begin{tabular}{|l|c|c|c|c|}
\hline Species & Bioacoustic survey & Mist-netting & Roost survey & Total \\
\hline Rhinolophus ferrumequinum & & 7 & 47 & 54 \\
\hline Rhinolophus hipposideros & & 2 & 18 & 20 \\
\hline Barbastella barbastellus & 11 & 27 & 8 & 46 \\
\hline Eptesicus nilssonii & 1 & 1 & & 2 \\
\hline Eptesicus serotinus & 3 & 5 & 2 & 10 \\
\hline Hypsugo savii & 48 & 38 & & 86 \\
\hline Myotis bechsteinii & & 2 & & 2 \\
\hline Myotis daubentonii & 12 & 41 & 3 & 56 \\
\hline Myotis emarginatus & 1 & 54 & 1 & 56 \\
\hline Myotis myotis & & 6 & & 6 \\
\hline Myotis mystacinus & 11 & 9 & 1 & 10 \\
\hline Myotis nattereri & & 3 & 1 & 15 \\
\hline Myotis oxygnathus & 22 & 10 & 1 & 12 \\
\hline Nyctalus leisleri & 14 & 8 & 1 & 23 \\
\hline Pipistrellus kuhlii & 6 & & & 6 \\
\hline Pipistrellus nathusii & 109 & 34 & 15 & 158 \\
\hline Pipistrellus pipistrellus & 1 & 12 & 1 & 2 \\
\hline Pipistrellus pygmaeus & & & & 17 \\
\hline Plecotus auritus & 250 & & & 1 \\
\hline Plecotus macrobullaris & & & & 627 \\
\hline Tadarida teniotis & & & & 13 \\
\hline Total & & & & 1 \\
\hline
\end{tabular}


Tab. 2 - Biometric measurements (average) for bats captured within the study area.

\begin{tabular}{|c|c|c|c|c|c|c|c|c|c|c|}
\hline & Sex & $\mathbf{N}$ & $\begin{array}{c}\text { Foream } \\
\text { mm }\end{array}$ & SD & $\begin{array}{c}\mathbf{5} \\
\text { Finger } \\
\mathbf{m m}\end{array}$ & SD & $\begin{array}{l}\text { Tibia } \\
\text { mm }\end{array}$ & SD & $\begin{array}{c}\text { Body } \\
\text { Mass } \\
\text { gr }\end{array}$ & SD \\
\hline \multirow[t]{2}{*}{ Myotis emarginatus } & $\mathrm{M}$ & 42 & 36.69 & 1.17 & 48.50 & 0.90 & 16.90 & 0.95 & 7.24 & 0.66 \\
\hline & $\mathrm{F}$ & 12 & 37.29 & 0.71 & 49.50 & 0.90 & 17.30 & 0.91 & 7.73 & 0.66 \\
\hline \multirow[t]{2}{*}{ Myotis daubentonii } & $\mathrm{M}$ & 35 & 36.88 & 1.17 & 47.13 & 1.74 & 16.79 & 0.94 & 7.54 & 0.93 \\
\hline & $\mathrm{F}$ & 6 & 37.76 & 1.30 & 48.38 & 2.06 & 17.07 & 0.69 & 7.00 & 0.75 \\
\hline \multirow[t]{2}{*}{ Hypsugo savii } & $\mathrm{M}$ & 25 & 34.15 & 1.50 & 42.00 & 1.48 & 14.16 & 0.65 & 7.31 & 0.50 \\
\hline & $\mathrm{F}$ & 13 & 34.57 & 0.59 & 42.95 & 1.59 & 14.24 & 0.62 & 8.30 & 1.33 \\
\hline \multirow[t]{2}{*}{ Pipistrellus pipistrellus } & $\mathrm{M}$ & 21 & 30.52 & 0.76 & 37.04 & 1.53 & 11.43 & 0.79 & 4.62 & 0.45 \\
\hline & $\mathrm{F}$ & 13 & 31.43 & 0.89 & 38.25 & 2.07 & 11.89 & 0.58 & 4.99 & 0.67 \\
\hline \multirow[t]{2}{*}{ Barbastella barbastellus } & $\mathrm{M}$ & 21 & 39.04 & 0.38 & 51.20 & 0.95 & 19.65 & 0.64 & 8.16 & 0.4 \\
\hline & $\mathrm{F}$ & 6 & 39.37 & 1.29 & 53.25 & 1.50 & 19.44 & 0.61 & 8.70 & 0.21 \\
\hline \multirow{2}{*}{ Plecotus auritus } & $\mathrm{M}$ & 9 & 39.09 & 1.43 & 51.00 & 1.51 & 19.70 & 0.88 & 7.06 & 0.41 \\
\hline & $\mathrm{F}$ & 3 & 40.57 & 1.72 & 51.50 & 1.50 & 19.90 & 0.80 & 9.75 & 1.41 \\
\hline \multirow[t]{2}{*}{ Myotis oxygnathus } & M & 10 & 58.37 & 1.87 & 74.50 & 1.82 & 26.49 & 1.24 & 26.94 & 1.97 \\
\hline & $\mathrm{F}$ & 1 & 60.23 & & 76.50 & & 26.51 & & 22.24 & \\
\hline \multirow[t]{2}{*}{ Nyctalus leisleri } & $\mathrm{M}$ & 5 & 43.00 & 0.93 & 47.67 & 2.30 & 17.19 & 1.11 & 14.37 & 2.16 \\
\hline & $\mathrm{F}$ & 5 & 43.01 & 1.42 & 47.00 & 1.50 & 16.06 & 0.97 & 14.90 & 1.38 \\
\hline \multirow[t]{2}{*}{ Pipistrellus kuhlii } & $\mathrm{M}$ & 5 & 32.99 & 1.70 & 45.00 & 1.51 & 14.40 & 1.09 & 5.37 & 0.83 \\
\hline & $\mathrm{F}$ & 3 & 33.73 & 1.89 & 45.50 & 1.45 & 14.60 & 1.10 & 6.53 & 0.28 \\
\hline \multirow[t]{2}{*}{ Myotis mystacinus } & M & 7 & 35.11 & 0.86 & 44.63 & 1.54 & 16.57 & 1.12 & 5.90 & 0.82 \\
\hline & $\mathrm{F}$ & 2 & 35.53 & 0.18 & 46.00 & 0.90 & 16.88 & 1.00 & 5.70 & 0.28 \\
\hline \multirow[t]{2}{*}{ Rhinolophus ferrumequinum } & $\mathrm{M}$ & 7 & 56.06 & 1.78 & 67.25 & 2.32 & 23.87 & 1.42 & 19.07 & 3.87 \\
\hline & $\mathrm{F}$ & & & & & & & & & \\
\hline \multirow[t]{2}{*}{ Myotis myotis } & $\mathrm{M}$ & 6 & 61.67 & 2.05 & 78.70 & 2.22 & 26.15 & 0.98 & 27.34 & 0.97 \\
\hline & $\mathrm{F}$ & & & & & & & & & \\
\hline \multirow[t]{2}{*}{ Eptesicus serotinus } & $\mathrm{M}$ & 4 & 51.94 & 0.78 & 63.50 & 1.95 & 22.19 & 0.33 & 26.13 & 1.77 \\
\hline & $\mathrm{F}$ & 1 & 51.06 & & 61.05 & & 21.28 & & 22.80 & \\
\hline \multirow[t]{2}{*}{ Myotis nattereri } & $\mathrm{M}$ & 2 & 37.80 & 1.13 & 50.50 & 1.90 & 17.00 & 0.33 & 7.50 & 0.70 \\
\hline & $\mathrm{F}$ & 1 & 38.00 & & 51.00 & & 17.10 & & 7.00 & \\
\hline \multirow[t]{2}{*}{ Myotis bechsteinii } & $\mathrm{M}$ & 2 & 42.33 & 0.90 & 53.00 & 1.00 & 22.00 & 0.87 & 9.60 & 1.12 \\
\hline & $\mathrm{F}$ & & & & & & & & & \\
\hline \multirow[t]{2}{*}{ Rhinolophus hipposideros } & M & 1 & 39.90 & & 48.00 & & 17.21 & & 5.60 & \\
\hline & $\mathrm{F}$ & 1 & 37.80 & & 48.00 & & 17.72 & & 5.80 & \\
\hline \multirow[t]{2}{*}{ Eptesicus nilssonii } & M & 1 & 40.26 & & 49.50 & & 18.35 & & 10.40 & \\
\hline & $\mathrm{F}$ & & & & & & & & & \\
\hline \multirow[t]{2}{*}{ Plecotus macrobullaris } & M & 1 & 40.68 & & 50.00 & & 19.57 & & 6.70 & \\
\hline & $\mathrm{F}$ & & & & & & & & & \\
\hline
\end{tabular}




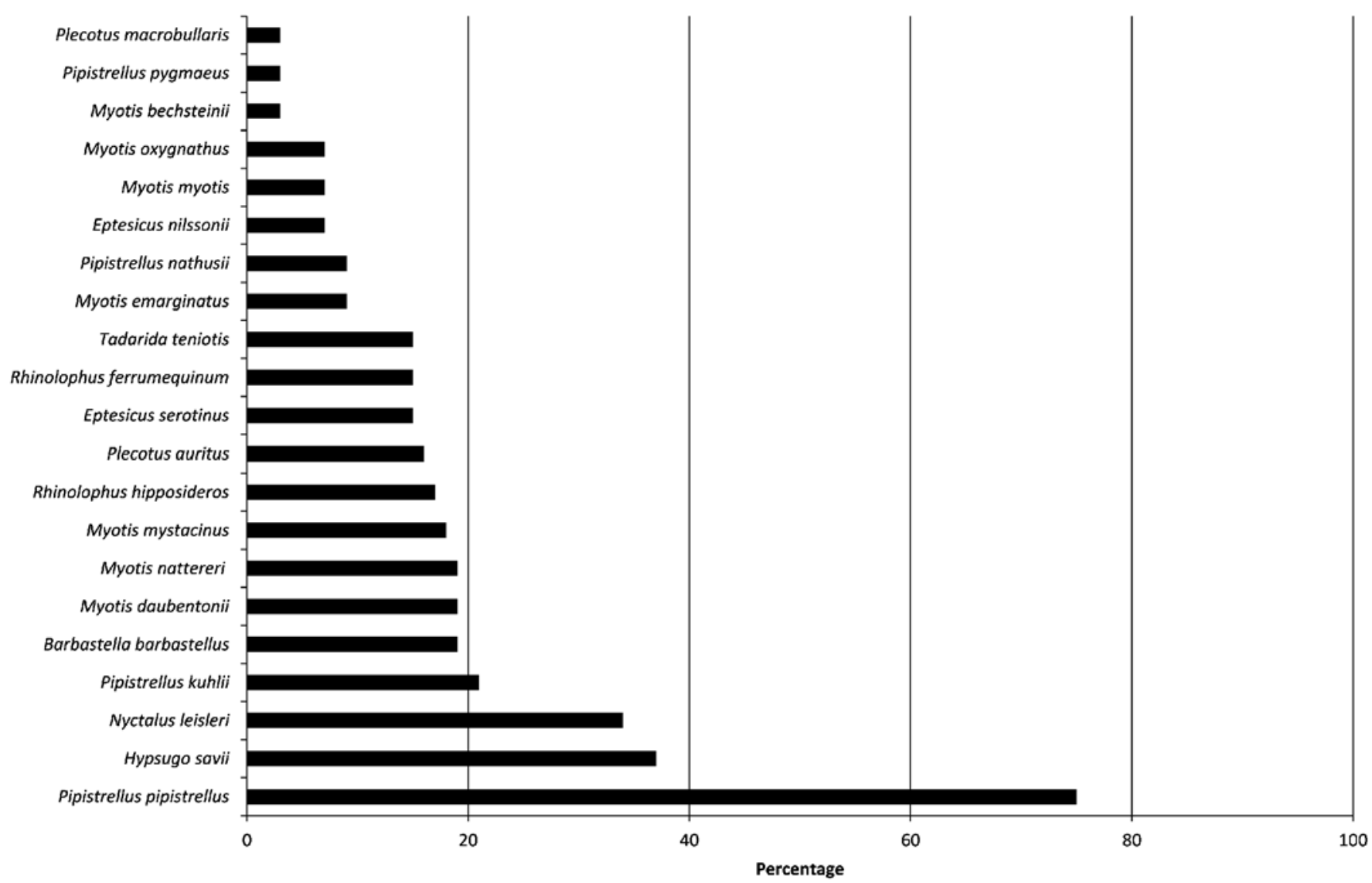

Fig. 2 - Percentage frequency of $1 \mathrm{~km}$ grid cells size in which every species was reported. / Frequenza percentuale del numero di griglie chilometriche in cui sono state segnalate le differenti specie.

\section{Rhinolophus ferrumequinum (Schreber, 1774)}

Risk Level Europe: Near Threatened - NT (Temple \& Terry, 2007).

Italy: Vulnerable - VU (Rondinini et al., 2013).

The species was found in the lower valleys, up to $900 \mathrm{~m}$ a.s.1. Individuals in hibernation were observed in nine natural and artificial cavities in Roaschia, Valdieri and Vernante municipality. Between winters $1995 / 1996$ and $2014 / 2015,7$ to 16 individuals were detected in hibernation inside Grotte del Bandito caves and neighbouring bunkers (Roaschia), with a population trend presenting severe fluctuations over years (Fig. 3). During late summer, up to 7 males were captured in a single night at the entrance of the Grotte del Bandito caves.

\section{Rhinolophus hipposideros (Bechstein, 1799)}

Risk Level Europe: Near Threatened - NT (Temple \& Terry, 2007).

Italy: Endangered - EN (Rondinini et al., 2013).

A total of 11 roosts used by Rhinolophus hipposideros were identified: 6 were underground cavities and 5 were man-made structures (churches, houses and bridges) up to an altitude of $1100 \mathrm{~m}$. Two of these are used for breeding in Limone municipality where 10 females were counted in 2011, before birth period, and in Valdieri municipality where a total of 8-11 females before birth pe- riod as well, in the period between 2004 and 2014. The presence of adults with flying youngsters in another location (but still within the study area) suggests the presence of other breeding sites as yet unknown. Temporary roosts used by adults and young were found in underground sites, buildings and in one case in a bridge along the Gesso river. In winter, this species was found infrequently, with some individuals in 4 underground cavities in the study area.

\section{Barbastella barbastellus (Schreber, 1774)}

Risk Level Europe: Vulnerable - VU (Temple \& Terry, 2007).

Italy: Endangered - EN (Rondinini et al., 2013).

This species was found hibernating with only one individual each time in two cavities of Grotte del Bandito caves and Vernante municipality. It was observed at Grotte del Bandito during winter 2005/2006 for the first time and it is now regularly present with a single individual each year. Here 27 individuals were also mist-netted ( 21 males and 6 females) between August and October, suggesting a swarming activity for the species (Toffoli \& Culasso, 2010). It was furthermore identified (with bioacoustic methods) during foraging activity at different locations inside or near deciduous forests up to an altitude of $1600 \mathrm{~m}$. 


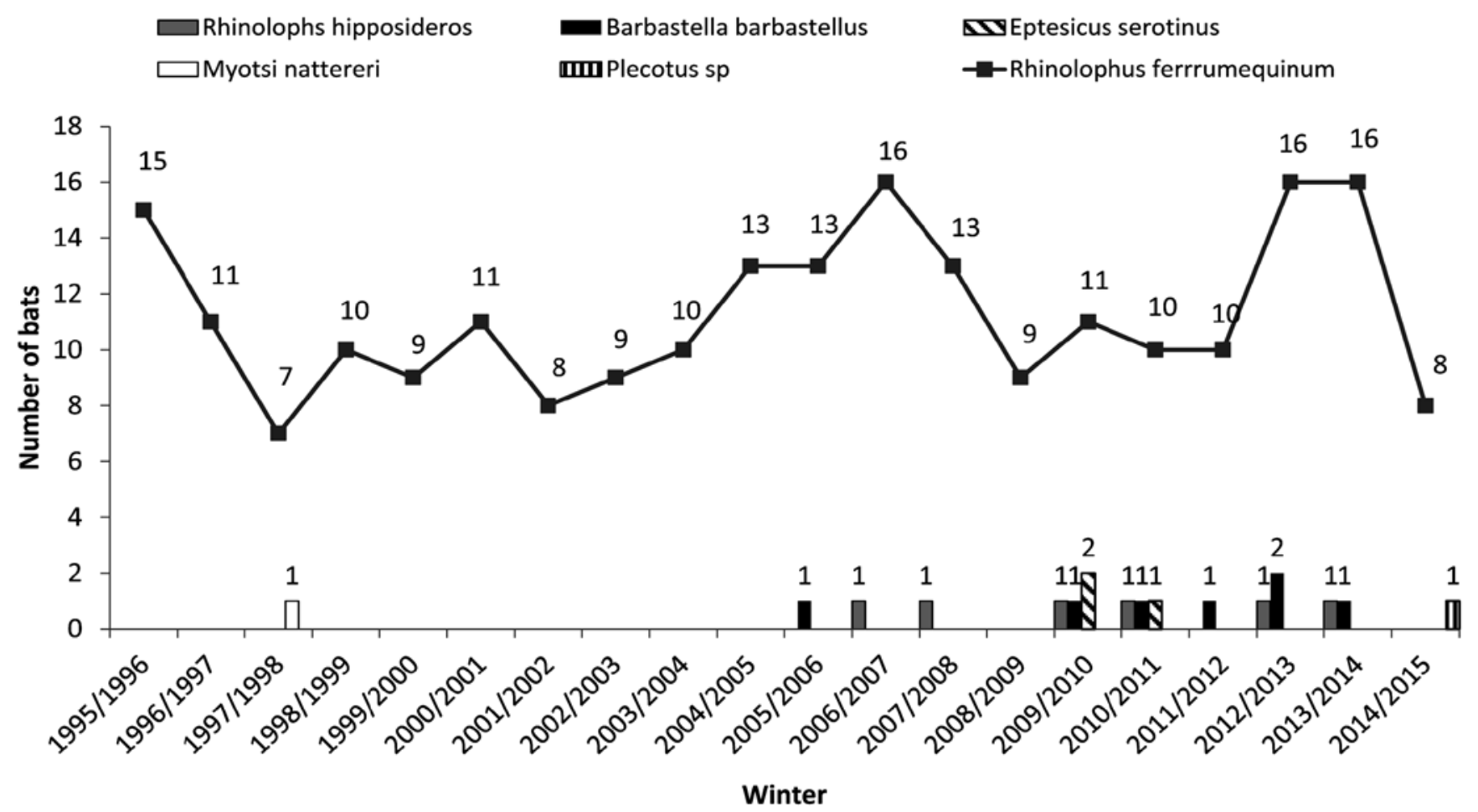

Fig. 3 - Trend of hibernating individuals (counted from $15^{\text {th }}$ December to $15^{\text {th }}$ February) for each observed bat species in the Grotte del Bandito caves and in neighbouring bunkers and tunnels (Roaschia). / Trend del numero d'individui in ibernazione (contati nel periodo compreso tra il 15 dicembre e il 15 febbraio) delle differenti specie di chirotteri osservate nelle Grotte del Bandito e nei vicini bunker e gallerie (Roaschia).

\section{Eptesicus nilssonii (Keyserling \& Blasius, 1839)}

Risk Level Europe: Least Concern - LC (Temple \& Terry, 2007).

Italy: Data Deficient - DD (Rondinini et al., 2013).

Some individuals were detected with bioacoustic methods during foraging activity in Valasco Valley (Valdieri) at $1750 \mathrm{~m}$ a.s.1. on $31^{\text {st }} \mathrm{July}, 2011$. A male was caught in a mist-net in Lourousa Valley (Valdieri) at $1800 \mathrm{~m}$ a.s.l. on $12^{\text {th }}$ July, 2012.

\section{Eptesicus serotinus (Schreber, 1774)}

Risk Level Europe: Least Concern - LC (Temple \& Terry, 2007).

Italy: Near Threatened - NT (Rondinini et al., 2013).

The species was observed in 6 different locations up to an altitude of $1500 \mathrm{~m}$. In two sites it was detected with bioacoustic methods. At the Grotte del Bandito caves 1 ot 2 were observed in hibernation in two consecutive winters. Five individuals were captured in three different locations in Roaschia, Vernante and Limone municipality at the entrance of cavities or along waterways.

\section{Hypsugo savii (Bonaparte, 1837)}

Risk Level Europe: Least Concern - LC (Temple \& Terry, 2007).

Italy: Least Concern - LC (Rondinini et al., 2013).

This is one of the most detected species up to $2000 \mathrm{~m}$ a.s.l. at Colle di Tenda (Limone). All available data refer to bioacoustic surveys and catches with mist-nets: all 38 individuals were captured along waterways ( 25 males and 13 females). All females were captured below 1000 $\mathrm{m}$ a.s.l., while males were captured up to $1800 \mathrm{~m}$ a.s.l. Nursing and pregnant females were captured until the first week of August.

\section{Myotis bechsteinii (Kuhl, 1817)} 2007).

Risk Level Europe: Vulnerable - VU (Temple \& Terry,

Italy: Endangered - EN (Rondinini et al., 2013).

Two males were captured at Grotte del Bandito caves (Roaschia) on $26^{\text {th }}$ August, 2011 and on $10^{\text {th }}$ September, 2014.

\section{Myotis daubentonii (Kuhl, 1817)}

Risk Level Europe: Least Concern - LC (Temple \& Terry, 2007).

Italy: Least Concern - LC (Rondinini et al., 2013).

The species was detected in 11 different locations during bioacoustic surveys, catches and roost searches, up to an altitude of $1900 \mathrm{~m}$. Temporary roosts used by single individuals were localized in some of the bridges along the Gesso valley and in some natural and artificial cavities in Roaschia and Limone municipality. Thirty-five males and 6 females were caught using mist-nets at the entrance of cavities or over water bodies. This species represents the most frequently captured species after Myotis emarginatus.

\section{Myotis emarginatus (Geoffroy, 1806)}

Risk Level Europe: Least Concern - LC (Temple \& Terry, 2007).

Italy: Near Threatened - NT (Rondinini et al., 2013). 
The species was caught at the entrance of three natural and artificial cavities at Grotte del Bandito caves and in Vernante municipality, with a total of 54 individuals (42 males and 12 females). Grotte del Bandito has probably been a swarming site for the species, at least until 2003 (Toffoli \& Culasso, 2010). Thereafter it appears that the site was deserted by the species. In the other two underground sites single individuals were captured in 2010 and 2011.

\section{Myotis myotis (Borkhausen, 1797)}

Risk Level Europe: Least Concern - LC (Temple \& Terry, 2007).

Italy: Vulnerable - VU (Rondinini et al., 2013).

This species was detected in two places only: Grotte del Bandito caves (Roaschia) and at the entrance of an artificial cavity in Limone municipality at $1500 \mathrm{~m}$ a.s.l. where 6 males were caught with mist-nets.

\section{Myotis mystacinus (Kuhl, 1817)}

Risk Level Europe: Least Concern - LC (Temple \& Terry, 2007).

Italy: Vulnerable - VU (Rondinini et al., 2013).

Seven individuals were caught over the water and near cavity entrances in 4 different locations in Entracque, Valdieri and Limone municipality up to an altitude of $1500 \mathrm{~m}$. A breeding roost was found in a residential building in San Giacomo d'Entracque during summer 1996, at $1250 \mathrm{~m}$ a.s.l. frequented by approximately 10 females. Here two youngsters were captured on $24^{\text {th }}$ and $29^{\text {th }} \mathrm{Au}-$ gust 1996 (Toffoli, 1999). The use of this roost by bats was checked up until 2005.

\section{Myotis nattereri (Kuhl, 1817)}

Risk Level Europe: Least Concern - LC (Temple \& Terry, 2007).

Italy: Vulnerable - VU (Rondinini et al., 2013).

Several individuals were detected with bioacoustic methods or mist-nets up to an altitude of $1750 \mathrm{~m}$. Two males and one female were captured at the entrance of Grotte del Bandito caves, where a lethargic individual was also observed during winter 1997/1998.

\section{Myotis oxygnathus (Monticelli, 1885)}

Risk Level Europe: Near Threatened - NT (Temple \& Terry, 2007).

Italy: Vulnerable - VU (Rondinini et al., 2013).

This species was found in two locations: in Grotte del Bandito caves and in an artificial tunnel at $1500 \mathrm{~m}$ a.s.l. in Limone municipality. At the first location, 3 males were captured in mist-nets, while 7 males and 1 female were caught at the second site, suggesting that the tunnel might be used for swarming activity. An individual was observed in Grotte del Bandito caves on $26^{\text {th }}$ November, 2005 .

\section{Nyctalus leisleri (Kuhl, 1817)}

Risk Level Europe: Least Concern - LC (Temple \& Terry, 2007).

Italy: Near Threatened - NT (Rondinini et al., 2013).

This is one of the most common bat species in the study area, detected in $32.0 \%$ of kilometric cells in the study area up to an altitude of $2000 \mathrm{~m}$. A temporary roost used by 1-2 individuals was located under the roof of a residential building in Palanfrè (Vernante) during summer 2011 at $1450 \mathrm{~m}$ a.s.l. Ten individuals (5 males and 5 females) were captured nearby waterways in the Gesso valley. Although breeding sites were not identified, post-lactating females were captured, indicating that the species probably reproduces within the study area.

\section{Pipistrellus kuhlii (Kuhl, 1817)}

Risk Level Europe: Least Concern - LC (Temple \& Terry, 2007).

Italy: Least Concern - LC (Rondinini et al., 2013).

This species was detected several times up to $1450 \mathrm{~m}$ a.s.l., nearby the locality of Palanfrè (Vernante), where single males were also captured on $2^{\text {nd }}$ and $12^{\text {th }}$ August, 2006. A reproductive roost located in a roof was found in Entraque (850 m a.s.1.). Here 30 individuals and 42 individuals were respectively counted exiting the roost on $23^{\text {rd }}$ August, 1995 and on $12^{\text {th }}$ July, 2009.

\section{Pipistrellus nathusii (Keyserling \& Blasius, 1839)}

Risk Level Europe: Least Concern - LC (Temple \& Terry, 2007).

Italy: Near Threatened - NT (Rondinini et al., 2013).

This species was only identified by bioacoustic analysis at three different localities in Valdieri, Vernante and Limone municipality, where its species-specific social calls were recorded between the end of July and the beginning of September (Fig.4).

\section{Pipistrellus pipistrellus (Schreber, 1774)}

Risk Level Europe: Least Concern - LC (Temple \& Terry, 2007).

Italy: Least Concern - LC (Rondinini et al., 2013).

This is the most common species present in the study area. It is found in $75.0 \%$ of the kilometric grid, in which the area was divided. It was identified using bioacoustics analysis and roosts survey. Furthermore, it was also caught in mist-nets up to an altitude of $2100 \mathrm{~m}$. Five reproductive roosts were found with a minimum of 21 individuals up to a maximum of 50 and further 6 temporary roosts frequented by single individuals were also identified. In total 34 individuals (21 males and 13 females) were captured in foraging areas and above water bodies.

\section{Pipistrellus pygmaeus (Leach, 1825)}

Risk Level Europe: Least Concern - LC (Temple \& Terry, 2007).

Italy: Data Deficient - DD (Rondinini et al. 2013).

This species was only observed in Valdieri municipality, where single individuals were surveyed during hunting alongside the Gesso river between August and September. A temporary roost, used by at least 2 individuals, was found in a bridge in the same locality.

\section{Plecotus auritus (Linnaeus, 1758)}

Risk Level Europe: Least Concern - LC (Temple \& Terry, 2007). 


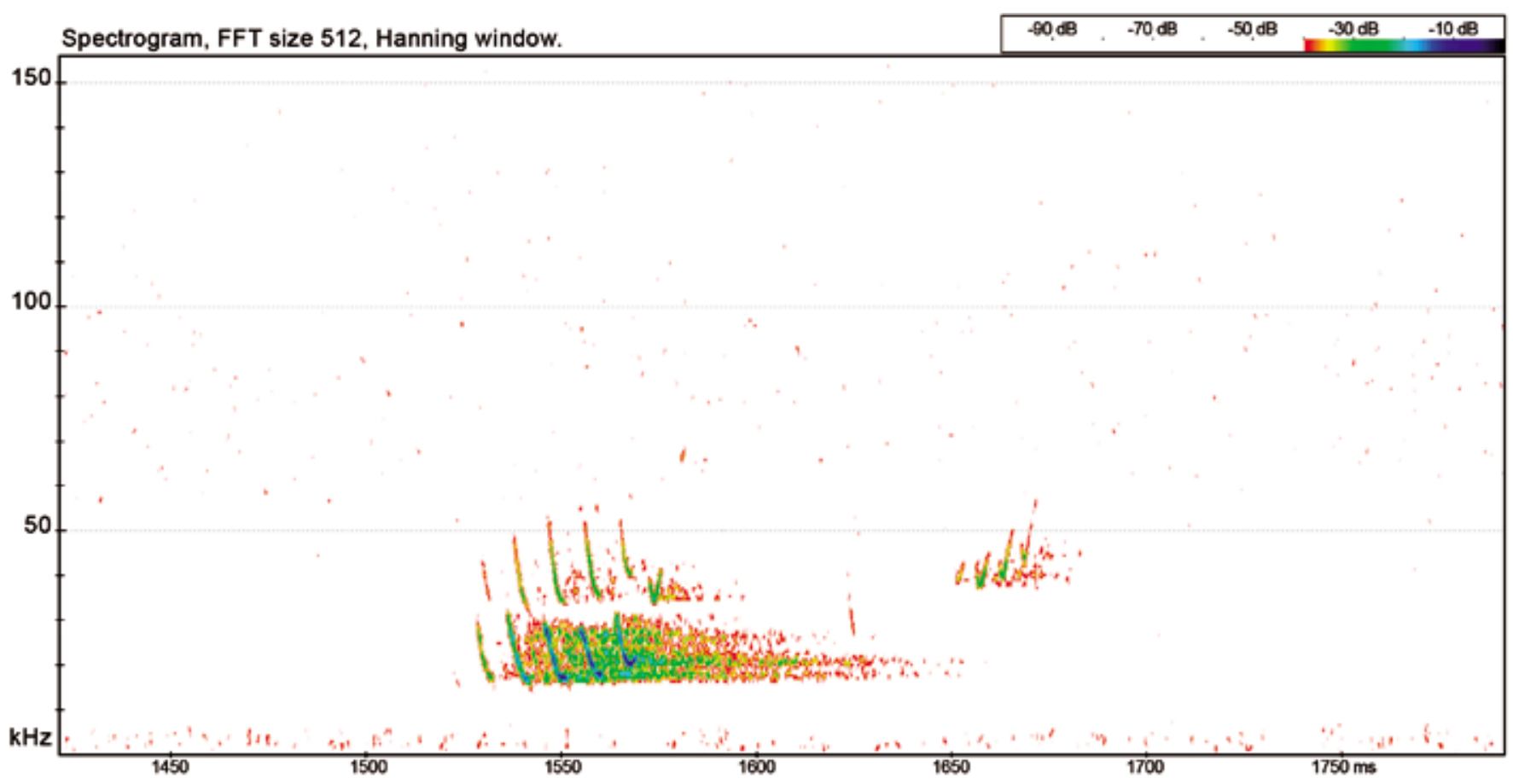

Fig. 4 - Social calls of Pipistellus nathusii were recorded with an Elekon Batlogger on $30^{\text {th }}$ August 2011 at Valdieri. / Grida sociali di Pipistellus nathusii registrati con Elekon Batlogger il 30 agosto 2011 a Valdieri.

Italy: Near Threatened - NT (Rondinini et al., 2013).

Twelve individuals ( 9 males and 3 females) were captured with mist-nets nearby water bodies at the entrance of some caves (up to an altitude of $1900 \mathrm{~m}$ ). Three roosts were identified in Valdieri municipality, one of which was a breeding roost located under a church roof and used by approximately 20 females. The other two roosts were temporary and only single individuals were observed in each.

\section{Plecotus macrobullaris (Kuzjakin, 1965)}

Risk Level Europe: Near Threatened - NT (Temple \& Terry, 2007).

Italy: Data Deficient - DD (Rondinini et al., 2013).

A single male was captured with a mist-net at the entrance of Grotte del Bandito caves on $7^{\text {th }}$ August, 2008.

\section{Tadarida teniotis (Rafinesque, 1814)}

Risk Level Europe: Least Concern - LC (Temple \& Terry, 2007).

Italy: Least Concern - LC (Rondinini et al., 2013).

The species was identified with bioacoustic analysis at several locations within the study area up to $2000 \mathrm{~m}$ a.s.l. Two roosts were located in south facing rock face cracks at the bottom of the Gesso valley (Valdieri municipality); 15 individuals were counted at the first site and 4 at the second during the night time exit phase.

\section{DISCUSSION AND CONCLUSIONS}

The present study provides information on the presence and conservation status of the bat fauna at Alpi Marittime Nature Park and related SCI, contributing to the knowledge on bats in the Southwest Italian Alps. The new checklist of 21 species is significantly larger than what was previously reported on the bat fauna of this alpine area (Toffoli, 1999). The species richness that was detected is a result of the broad diversity of habitats in the study area, resulting from the variety of climatic, geological and altitudinal gradients of the park. Bat species typical of the mountain areas of the South-western Palearctic such as Plecotus macrobullaris were found alongside other central European - boreal species (Eptesicus nilssonii) or typically southern European species (Hypsugo savii, Tadarida teniotis) (Dietz \& Kiefer, 2014). Within the limits of a different sampling effort, the number of species reported appears to be high when compared to bat communities in other Alpine protected areas in Italy with similar or larger surface; e.g. Alpe Veglia e Alpe Devero Nature Park, where only 17 species were reported $(\mathrm{Cu}-$ lasso \& Toffoli, 2011), Adamello Brenta Nature Park, for which 19 species were counted (Chirichella et al., 2003), or Stelvio National Park, where only 20 species were reported (Spada et al., 2011).

The presence of two reproductive roosts of Rhinolophus hipposideros is of particular interest. This species was widespread in Piedmont in the first half of the last century (Gulino, 1938). Nevertheless, it has now become rare at regional level. Currently, it seems to be regularly present in the southern part of the region, where some reproductive and hibernation roosts are known, while observations for the northern part are still scarce (Debernardi et al., 2010). No evidence of reproductive activity for the Barbastella barbastellus was directly observed. However, the fact that the species was frequently observed foraging suggests there are breeding sites in this area. For 
Eptesicus nilssonii, Pipistrellus pygmaeus and Plecotus macrobullaris, new information gathered in this study has improved knowledge about their distribution in Italy, since these species are classified Data Deficient at national level (Rondinini et al., 2013). Especially for Eptesicus nilssonii, our records extend the range of this species in the Italian Western Alps, while previously it was thought to be limited to Central and Eastern Alps (Lanza, 2012) as the most western observations were reported in VerbanoCusio-Ossola (Culasso \& Toffoli, 2011). In the French Western Alps, this species is present in all regions from Haute Savoie to Mercantour near the Italian border (Barataud et al., 1998; Groupe Chiroptères de la LPO RhoneAlpes, 2014). Last but not least, observations of Pipistrellus pygmaeus and Plecotus macrobullaris contribute to better define their distribution in Piedmont. Plecotus macrobullaris has been reported only in the Verbano-CusioOssola area (Trizio et al., 2003; Debernardi \& Patriarca, 2007), Aosta Valley (Debernardi \& Patriarca, 2008) and Liguria (Spitzenberger et al., 2001). Pipistrellus pygmae$u s$ has been reported rarely in Piedmont and Aosta Valley (Debernardi and Patriarca, 2008; Toffoli, 2011), and France near the Italian border (Arthur \& Lemaire, 2009; Groupe Chiroptères de la LPO Rhone-Alpes, 2014). In conclusion, the high level of biodiversity for bats found in the Alpi Marittime SCI indicates that protection measures adopted in this area may play an important role towards the conservation of bats in Italy.

\section{Acknowledgements}

The research was conducted with partial funding from the Alpi Marittime Nature Park within the Project Alcotra PIT "Knowledge of the biodiversity and natural heritage: the Biological Generalized Inventory", to which goes the most heartfelt thanks for the cooperation. We thank all the people who have collaborated during the field activities, in particular: Mara Calvini, Albino Gosmar, Arturo Pellegrino and Marco Rughetti.

\section{REFERENCES}

Agnelli P., Martinoli A., Patriarca E., Russo D., Scaravelli D. \& Genovesi P., 2004 - Linee Guida per il monitoraggio dei Chirotteri: indicazioni metodologiche per lo studio e la conservazione dei pipistrelli in Italia. Quaderni di Conservazione della Natura, Ministero Ambiente - Istituto Nazionale Fauna Selvatica, 19.

Arthur L. \& Lemaire M., 2009 - Le Chauves-souris de France, Belgique, Luxembourg et Suisse. Biotope Edition - Muséum national d'Histoire naturelle, Paris.

Barataud, M., 2005 - Acoustic variability and identification possibilities in 7 species of the genus Myotis. Proc. $5^{\text {th }}$ Eur. Bat Det. Work. Tronçais, August 2002. Le Rhinolophe, 17: 43-62.

Barataud, M., 2012 - Écologie acoustique des chiroptères d'Europe: identification des espèces, étude de leurs habitats et comportements de chasse. Biotope Edition.

Barataud M., Joulot C. \& Demontoux D., 1998 - Synthèse des données sur la répartition en France d'Eptesicus nilssoni (Keyserling \& Blasius, 1839) et de Vespertilio murinus (Linnaeus, 1758). Le Rhinolophe, 13: 23-28.
Brunet-Rossini A.K. \& Wilkinson G.S., 2009 - Methods for age estimation and the study of senescence. In: Bat ecological and behavioral methods for the study of bats. Kunz T.H. \& Parson S. (eds.). Johns Hopkins University Press, Baltimore.

Chirichella, R., Mattiroli, S., Nodari, M., Preatoni, D., Wauters, L., Tosi, G. \& Martinoli, A., 2003 - The Adamello-Brenta Natural Park bat community (Mammalia, Chiroptera): distribution and population status. Hystrix, the Italian Journal of Mammalogy, 14 (1-2): $29-45$.

Culasso P. \& Toffoli R., 2011 - I Chirotteri del Parco Naturale Alpe Veglia e Alpe Devero e del SIC/ZPS IT1140016 "Alpe Veglia e Devero-Monte Giove". Relazione inedita, Regione Piemonte - Ente di Gestione delle Aree Protette dell'Ossola.

Debernardi P. \& Patriarca E., 2007 - The bats of the Lake Maggiore piedmont shore (NW Italy). Hystrix, the Italian Journal of Mammalogy, 18 (1).

Debernardi P. \& Patriarca E., 2008 - Prima segnalazione di Myotis bechsteinii, Myotis daubentonii, Myotis nattereri, Nyctalus leisleri, Pipistrellus pygmaeus, Plecotus macrobullaris e Tadarida teniotis in Valle d'Aosta. Aggiornamento dell'inventario dei chirotteri noti per la regione. Revue Valdôtaine d'Histoire Naturelle (2007-2008): 61-62.

Debernardi P, Patriarca E. \& Toffoli R., 2010 - Monitoraggio delle colonie di Chirotteri riproduttive e svernanti di particolare interesse conservazionistico note in Piemonte e dati preliminari sull'attività di swarming. Relazione inedita, Regione Piemonte, Parco Naturale Laghi di Avigliana.

Denzinger A., Siemers B.M., Schaub A. \& Schnitzler H.U., 2001 - Echolocation by the barbastelle bat, Barbastella barbastellus. Journal of Comparative Physiology A, 187 (7): 521-528.

Dietz C. \& Kiefer A., 2014 - Die Fledermäuse Europas. Kennen, Bestimmen, Schützen. Kosmos Verlag, Stuttgart.

Dietz C. \& Von Helversen O., 2004 - Illustrated identification key to the bats of Europe. Electronic Publication Version 1.0. Released 15.12.2004. Tuebingen \& Erlangen, Germany.

Dietz C., Von Helversen O. \& Nill D., 2009 - Bats of Britain, Europe and Northwest Africa. Helm eds.

Groupe Chiroptères de la LPO Rhone-Alpes, 2014 - Les chauves souris de Rhone-Alpes. LPO Rhone-Alpes, Lyon.

Gulino G., 1938 - I Chirotteri del Piemonte. Bollettino del Museo di Zoologia e Anatomia Comparata della Regia Università di Torino, 46: 1-56.

Haarsma A.J., 2008 - Manual for assessment of reproductive status, age and health in european vespertilionid bats. Electronic publication, first released 12-09-2008. Hillegom, Holland.

Lanza B., 2012 - Fauna d'Italia. Mammalia V. Chiroptera. Calderini Editore, Bologna, 47.

La Posta A. \& Duprè E., 2008 - La Fauna Italiana. Dalla Conoscenza alla Conservazione. Ministero dell'Ambiente e della Tutela del Territorio e del Mare. Direzione per la Protezione della Natura. 
Leccia M.F., 2012 - L'inventaire biologique généralisé Mercantour/Alpi Marittime: une example de collaboration réeussie entre gestionaires d'espaces protégé et taxinomistes. Bulletin de la Société zoologique de France, 137 (1-4): 25-31.

Locatelli A. \& Toffoli R., 2014 - Application of an habitat suitability model as a tool for the study of bats. In: $9^{\circ}$ Congresso Nazionale di Teriologia. Imperio S., Mazzaracca S., Preatoni D.G. (eds.). Hystrix, the Italian Journal of Mammalogy, 25 (Supplement).

Marchesi P., Blant M. \& Capt S. (eds.), 2008 - Clés de Détermination de mammifères de Suisse. Fauna Helvetica 21. $C S C F$ \& $S S B F$, Neuchatel.

Middleton N., Froud A. \& French K., 2014 - Social Calls of the Bats of Britain and Ireland. Pelagic Publishing Ltd.

Pettersson L., 2008 - BatSound. Real-time spectrogram sound analysis software for Windows. Pettersson Elektronik $A B$, Uppsala.

Pfalzer G., 2002 - Inter und intraspezifische Variabilität der Soziallaute heimischer Fledermausarten (Chiroptera, Vespertilionidae). Mensch und Buch Verlag, Berlin: $1-251$

Pfalzer G. \& Kusch, J., 2003 - Structure and variability of bat social calls: implications for specificity and individual recognition. Journal of Zoology, 261 (1): 2133.

Pierallini R., Keller A. \& Moretti M., 2004 - Chiave di determinazione dei Chirotteri (Mammalia) della Svizzera attraverso l'osservazione al microscopio ottico della struttura dei peli. Revue suisse de Zoologie, 111 (2): 381-394.

Puechmaille S.J., Allegrini B., Boston E.S., DubourgSavage M.J., Evin A., Knochel A. \& Teeling E.C., 2012 - Genetic analyses reveal further cryptic lineages within the Myotis nattereri species complex. Mammalian Biology-Zeitschrift für Säugetierkunde, 77 (3): 224-228

Roesli M.\& Moretti M.,2000-Chiave perl'identificazione dei pipistrelli della Svizzera. Centro Protezione Chirotteri Ticino, Dangio.

Rondinini C., Battistoni A., Peronace V. \& Teofili C., 2013 - Lista Rossa IUCN dei Vertebrati Italiani. Comitato Italiano IUCN e Ministero dell'Ambiente e della Tutela del Territorio e del Mare, Roma, 56.

Russo D. \& Jones G., 1999 - The social calls of Kuhl's pipistrelles Pipistrellus kuhlii (Kuhl, 1819): structure and variation (Chiroptera: Vespertilionidae). Journal of Zoology, 249 (4): 469-493.

Russo D. \& Jones G., 2002 - Identification of twentytwo bat species (Mammalia: Chiroptera) from Italy by analysis of time-expanded recordings of echolocation calls. Journal of Zoology, 258: 91-103.

Salicini I., Ibáñez C. \& Juste J., 2011 - Multilocus phylogeny and species delimitation within the Natterer's bat species complex in the Western Palearctic. Molecular Phylogenetics and Evolution, 61 (3): 888-898.

Sindaco R., Baratti N., \& Boano G., 1992 - I chirotteri del Piemonte e della Val d'Aosta. Hystrix, the Italian Journal of Mammalogy, 4 (1): 1-40.
Spada M., Bologna S., Mazzaracca S., Piccioli M., Preatoni D., Martinoli A., 2011 - Monitoraggio Chirotteri nel Parco Nazionale dello Stelvio. Relazione inedita, Parco Nazionale dello Stelvio.

Spitzenberger F., Pialek J. \& Haring E., 2001 - Systematics of the genus Plecotus (Mammalia, Vespertilionidae) in Austria based on morphometric and molecular investigations. Folia Zoologica, 50 (3): 161-172.

Temple H.J. \& Terry A. (eds.), 2007 - The Status and Distribution of European Mammals. Luxembourg: Office for Official Publications of the European Communities.

Toffoli R., 1999 - I Chirotteri delle Alpi Marittime. In: Atti $1^{\circ}$ Convegno Italiano sui Chirotteri (1999). Castell'Azzara 28-29 marzo 1998. Dondini G., Papalini O. \& Vergarsi S. (eds.): 147-153.

Toffoli R., 2011 - I Chirotteri del Parco naturale delle Capanne di Marcarolo. Regione Piemonte. Parco Naturale delle Capanne di Marcarolo.

Toffoli R. \& Culasso P., 2010 - Utilizzo autunnale di siti sotterranei da parte della chirotterofauna in Piemonte e definizione del loro ruolo ecologico (Mammalia, Chiroptera). Rivista piemontese di Storia naturale, 31 (2010): 265-278.

Trizio I., Patriarca E., Debernardi P., Preatoni D., Tosi G. \& Martinoli A., 2003 - The Alpine Long-Eared Bat (Plecotus alpinus Kiefer and Veith, 2001) is present also in Piedmont Region: first record revealed by DNA analysis. Hystrix, the Italian Journal of Mammalogy, $14(1-2)$.

Waters D.A., Rydell J. \& Jones, G., 1995 - Echolocation call design and limits on prey size: a case study using the aerial-hawking bat Nyctalus leisleri. Behavioral Ecology and Sociobiology, 37 (5): 321-328. 